\title{
The Control of Water Supplies
}

$\mathrm{T}$ HE first report of the Central Advisory Water Committee, just issued from the Ministry of Health (H.M. Stationery Office, $6 d$. net), summarizes the conclusions arrived at by the Committee on a number of suggestions submitted to it for new legisla. tion to facilitate the conservation and supply of water and the co-ordination of water interests. The most urgent of these questions, in the Committee's opinion, were proposals for $(a)$ the control and conservation of needed underground water resources and the protection of underground water from pollution; $(b)$ the planning of water resources and supplies; and (c) the modernization of the existing law relating to the supply of water by local authorities and water companies.

With regard to the first matter, the approved findings of a special underground water sub-committee are given in which it is recommended that control should be exercised only in defined areas in which the conservation of underground water is shown, after investigation, including public inquiry, to be necessary in the public interest, with the further recommendation that the Minister of Health should be empowered, either on his own initiative, or on the application of any interested regional advisory water committee or person, and after consultation with the Central Advisory Water Committee, to make orders defining areas in which control of the abstraction of underground water is necessary in the public interest. These, with certain other recommendations relating to waste and pollution of supplies, it is noted, will entail substantial amendment of the existing law, under which owners have the unrestricted right to abstract water from under their land, or to allow underground resources which they have tapped to run to waste ; they affect also, to some extent, the powers of owners to dispose of waste matters which may cause pollution. The Committee is satisfied, however, as to the necessity and value of the suggested provisions.

The second of the questions under consideration, namely, the planning of water resources and supplies, forms the subject of another special report by a sub- committee, in which it is pointed out that the regional planning of public water supplies by joint committees of water undertakers is of comparatively recent origin. There are now nine regional committees in existence, comprising areas with a total population of some fifteen millions. Although the central committee is satisfied as to the need for regional planning by regional committees, it considers the existing pro. cedure should be amended and that in place of volun. tary assistance in their researches, the regional committees should be empowered by statute to make precepts on constituent authorities for their expenses and to obtain necessary information of consumption and resources. The Minister of Health should, in the Committee's opinion, be empowered to require all persons abstracting water to furnish returns of any water abstracted and not returned to the stream from which it was taken, an exception being made in favour of private individuals who abstract water for their own domestic use. With certain reservations in regard to details, these returns should be made public to the extent of affording information in the aggregate of the quantity of water abstracted in suitable areas.

The reconstitution of the regional committees is advocated in order to obtain greater efficiency, a limit of 10 members in each being considered desirable, inclusive of an independent chairman. The lack of contact between water undertakers and other interests is met by the recommendation that it should be obligatory for the committees to consult all interested bodies, including catchment boards, fishery boards, harbour and navigation authorities and industrial users, before definite proposals are formulated in which the interests of these bodies are likely to be affected. Other recommendations are made for increasing the powers of the Minister of Health in regard to the formation or alteration of joint boards and the amalgamation and acquisition of water undertakings. As regards the modernization of the law relating to water supply, it is stated a consolidation bill is in course of being drafted for submission to the Minister of Health.

B. C.

\section{The Museums Association}

\section{Annual Conference at Belfast}

$\mathrm{T}$ HE forty-ninth Annual Conference of the Museums Association was held in Belfast in the week commencing July 4, and was attended by representatives of museums of all parts of Great Britain and by a number of delegates from overseas. The president, Dr. R. E. Mortimer Wheeler, announced that Her Majesty Queen Mary had graciously consented to become the patroness of the Association.

In his presidential address, Dr. Wheeler dealt with a number of current museum problems, and referred especially to the need for folk parks in England, and for the preservation, either there or elsewhere, of historic horse-drawn vehicles which have now become obsolete.

A large part of Dr. Wheeler's address was concerned with air raid precautions in museums and art galleries. The Museums Association has held a meeting on this subject, and has approached the Standing Commission on National Museums for advice. Museum buildings may be reinforced, deep basements or country house storage may be provided for objects of primary importance, and a plan prepared for immediate action in case of emergency. Any person, Dr. Wheeler said, who is directly or 
indirectly responsible for a museum or art gallery is neglecting an essential part of his duty if he is not taking all feasible steps to protect his collections from possible war risks.

A discussion on museums and field archæology, opened by Sir Cyril Fox, director of the National Museum of Wales, led to a general agreement that field work is a most important part of the training of museum officials who are in charge of archrological material. Not only does it enrich the museum, but it also provides officials with personal contacts, and a background of knowledge that is invaluable in the study of their own collections. Curators should be given facilities to take part in excavations as an official part of their museum work. In the same discussion, Mr. Christopher Hawkes of the British Museum directed attention to the need for a national archæological survey with centralized records.

"Youth in Museums" was a subject of three papers by Miss Mary S. Shaw, Miss C. Mirèio Legge and Miss Bertha Hindshaw, all of Manchester, who, from the point of view of an Egyptologist, a zoologist and the curator of a children's museum, discussed the way in which museum collections could be used for vivid educational work.

Mr. Trevor Thomas, of the Liverpool Public Museums, read an original and stimulating paper on the æsthetics and technique of museum display-a subject which is, perhaps, of little obvious concern to the scientific worker, but which is, nevertheless, of the very greatest importance if museum exhibits are to appeal to the visitor, whose attention is arrested by vigorous display, in which the objects are grouped and arranged in an attractive manner. In this connexion, the results of experimental psychology should not be neglected.

Mr. Frank Pick, of the London Passenger Transport Board, gave a vigorous address on the form and purpose of a local museum, which was illustrated by many comparisons between museums in Britain and those in other countries. The primary question is, he said, to whom or to what is a museum directed ? It is necessary for every museum to work to a specific aim and purpose, and specialized museums are needed; for example, Britain has no museum giving a synopsis of the history and development of agriculture, nor is there one dealing with the history, meaning and purpose of clothes. A museum can justify itself only as it establishes relationships with current life, and its administration is work requiring great imaginative activity.

Among other papers at the Conference, Mr. E. Rimbault Dibdin discussed the question "Are Art Galleries Obsolete ?" ; Mr. J. H. Hewitt talked of the place of reproductions in the gallery; $\mathbf{M r}$. A. F. Reeve Fowkes made a plea for a circulating national gallery, and Mr. J. A. S. Stendall described museum methods in Scandinavia. A film on the work of the Royal Scottish Museum was presented by its director, Mr. T. Rowatt.

Mr. S. F. Markham, discussing the future of the museum movement in Britain, made an informative and practical contribution. His views will no doubt be found expressed in detail in the report on this subject which he is preparing for the Carnegie United Kingdom Trustees.

About two hundred and thirty delegates attended the Conference, and were entertained by the Lord Mayor of Belfast, by the Belfast Museum Committee, and by Queen's University. There were excursions to the Giant's Causeway, to Armagh, and to archæological sites in Northern Ireland.

Next year's Conference will be held at Cheltenham in the week commencing July 3; it will be the jubilee of the Museums Association, and will be under the presidency of Viscount Bledisloe.

\section{International Physiological Congresses}

$\mathrm{T}$ HE sixteenth International Physiological Congress, which will be held in Zurich on August 14-19, may be considered to mark the fiftieth anniversary of the first congress, which was held in the same country. In honour of the occasion, F. J. Franklin has written a fascinating history of these congresses, which is published in Annals of Science (3, Part 3). It is illustrated with thirty-five photographs of presidents of the congresses and others who have contributed to their success. Copies are to be presented to all members.

Dr. Franklin gives a large number of details of the organization of these congresses which will be very useful to those responsible for congresses in the future, but he has done far more than this. He has managed to catch and convey something of the enthusiastic spirit which animated the early congresses, when about a hundred keen workers met together to demonstrate experiments to one another. Every effort was made to keep the arrangements as simple as possible, and particular stress was laid on the importance of demonstrations. There was at one time a movement in favour of abolishing other forms of communication altogether, but this was thought to be impracticable.
The first congress was the result of a letter sent by the Physiological Society, London, to 109 physiologists in 1888. It met the next year in Basle, and Dr. Franklin quotes interesting reminiscences of several of the eleven survivors. This congress was so successful that it was decided to hold similar congresses every three years, and they met successively at Liége, Bern, Cambridge, Turin, Brussels, Heidelberg, Vienna and Groningen (1913). Speeches were made which emphasized the international spirit of science, and it is sad to remember how this spirit was forgotten in the years of the Great War. The congress in Paris in 1920 was confined to physiologists from allied countries, and the next truly international congress was held in Edinburgh three years later. Since then congresses have been held in Stockholm, Boston, Rome and Leningrad. The membership has grown to about 1,500 and the scientific demonstrations have tended to be overshadowed by the banquets, concerts and sight-seeing expeditions which have been generously provided by the Governments of some of the countries which have acted as hosts.

An attempt is being made this year to return to the simplicity of the early congresses. Membership 